\title{
POR UMA ÉTICA DO AMOR FATI NO CURRÍCULO
}

\author{
Deniz, Alcione Nicolay
}

\section{Resumo}

Este texto apresenta uma série de argumentos sobre as relações entre currículo e ética. Procura, sobretudo, diagnosticar a natureza das forças que definem o caráter do ethos curricular. Para isso, além de situar exemplos da realidade do currículo nacional, investiga a composição das formas de agir disseminadas nas legislações oficiais dos sistemas de ensino. Partilha, como ferramenta de estudos, da filosofia nietzschiana, principalmente o recorte que assinala o período maduro da sua obra, a partir de 1881. O texto utiliza, também, o procedimento metodológico conhecido por perspectivismo. Conclui pela necessidade de pensar o diverso, animar a alegria, transgredir a norma a fim de executar o instante radical.

Palavras-chave: niilismo; formação; diferença

\section{FOR AN ETHICS OF LOVE FATI IN THE CURRICULUM}

\begin{abstract}
This text presents a series of arguments about the relationship between curriculum and ethics. Above all, it seeks to diagnose the nature of the forces that define the character of the curricular ethos. For this, in addition to locating examples of the reality of the national curriculum, it investigates the composition of the ways of acting disseminated in the official legislation of the education systems. It shares, as a study tool, Nietzschean philosophy, mainly the outline that marks the mature period of his work, from 1881 . The text also uses the methodological procedure known as perspectivism. It concludes by the need to think the diverse, to animate the joy, to transgress the norm in order to execut the radical moment.
\end{abstract}

Keywords: nihilism; formation; difference

\section{POR UNA ÉTICA DEL AMOR FATI EN EL CURRÍCULO}

\section{Resumen}

Este texto presenta una serie de argumentos sobre la relación entre currículo y ética. Sobre todo, busca diagnosticar la naturaleza de las fuerzas que definen el carácter del ethos curricular. Para ello, además de ubicar ejemplos de la realidad del currículo nacional, se investiga la composición de las formas de actuación difundidas en la legislación oficial de los sistemas educativos. Comparte, como herramienta de estudio, la filosofía nietzscheana, principalmente el trazo que marca el período de madurez de su obra, a partir de 1881 . El texto también utiliza el procedimiento metodológico conocido como perspectivismo. Concluye por la necesidad de pensar lo diverso, animar la alegría, transgredir la norma para correr el momento radical.

Palabras-clave: nihilismo; formación; diferencia 


\section{INTRODUÇÃO}

Este trabalho pretende explorar uma relação antiga, mas que sempre se renova em cada geração de jovens que chega à escola. Ela parte dos primórdios da Paideia grega, do instante em que palavras como educação e formação começaram a ser proferidas. Nesse instante, o trabalho com a mais complexa obra da natureza (o homem) merece atenção, uma vez que a sobrevivência da polis depende do cultivo de virtudes, habilidades, saberes. Tal forma de cultivo, entretanto, assume várias formas, várias maneiras e vários caminhos. Por vezes, alguns desses caminhos se cruzam; por outras, eles seguem solitários como navios que deixam o porto em direção à vastidão do oceano. Nesse percurso, as vivências que aprendemos nos roteiros que trilhamos não cabem no diário do navegador. Muitas aprendizagens se perdem na memória e lá permanecem como crisálidas adormecidas. Mas tanto o diário do navegador quanto as crisálidas adormecidas pertencem à materialidade do tempo e, no mesmo sentido, as metamorfoses do instante: o diário aberto, o bater de asas das borboletas. O que significa que toda relação, por mais antiga que seja, sempre renova os modos de ver, a variação das perspectivas. É assim a relação entre ética e currículo. Ela é interminável e problemática em sua extensão, de maneira que não conseguimos definir onde inicia, tampouco onde acaba.

Entretanto, criamos marcadores de abordagem, delimitações teórico-conceituais e seleção de referenciais de acordo com o que pretendemos abordar. Por isso, passamos a investigar a natureza do suposto ethos curricular, mais precisamente a natureza da ação política no currículo. A partir disso, procuramos observar resquícios de pseudoformação, ou seja, a condição ética que promove determinado grau de valores, mas acaba reproduzindo o ciclo representacional. Destacamos, inclusive, exemplos contemporâneos do currículo nacional, ainda que muito específicos naquilo que pretendemos, ou seja, superar o niilismo reativo como atmosfera de força no ambiente da educação básica. Ainda nessa direção, investigamos as influências filosóficas que erigiram as noções de cidadania, liberdade e cultura. Acreditamos que o sujeito não se realiza em nenhuma direção, porque não afirma sua vontade e nem deseja quebrar a tábua de valores legados da modernidade. Na sequência, como o quinto ato da tragédia grega, chegamos à grande razão do texto: a ética do amor fati no currículo. Para isso, percorremos as obras maduras do filósofo Nietzsche (1844-1900) a fim de situar tal expressão e traçar seus contornos no currículo.

Assim, desenvolvemos o presente trabalho acreditando que tempos melhores para os atores que fazem e vivem a escola não dependem apenas de gestores externos. Dependem da aceitação (de si mesmo, do outro e do momento), pois somente dessa maneira pode ocorrer resistência contra a banalidade do pensamento, contra os retrocessos das políticas públicas, contra a negação da vida. Aliás, na escala da valoração (como dizia o filósofo): o valor da vida não pode ser avaliado.

\section{ETHOS CURRICULAR}

Existe uma ética no currículo? Ora, se acreditamos em um poder centralizador, em um ethos hegemônico, em uma verdade definitiva, então uma ética pode significar um modelo-padrão de formação, ou melhor, uma espécie de mecanismo cujo modus operandi ensina a repetição e a obediência. Dessa forma, não haveria espaço à contradição, à diversidade, à multiplicidade, à diferença, uma vez que, calcada num dogma moral ou ideológico, tal condição ética do currículo estaria fadada, inevitavelmente, ao atraso cultural. Imaginamos uma realidade tão diversa quanto a realidade brasileira, num país tão extenso e multicultural, com espaços geográficos e territoriais distintos, haveria sentido a evocação de um modelo ético? Mesmo que tal modelo aparecesse salpicado por matizes conservadoras, liberais, progressistas, técnico-científicas, ainda assim existe 
(por meio desse modelo) a insistência persuasiva de aplicar à ação pedagógica a marca de determinado padrão moral. Portanto a pergunta inicial carece de reformulação, simples e básica, condenada pelo artigo indefinido, ela se torna seminua de sentido e direta na economia das palavras: existe ética no currículo?

Agora, sim. De maneira mais orgânica, familiar e sonante aos ouvidos, a pergunta remete ao sentido de toda a educação escolarizada, talvez de todo o objetivo final do processo pedagógico. Dificilmente poderíamos imaginar um currículo sem ética, a menos que tal currículo não tivesse por horizonte a formação para a cidadania, para o trabalho, para a vida em sociedade. Também não seria absurdo afirmar que, considerando tamanha ausência, talvez o ator principal (aquele que sofre e pratica a ação) nem fosse uma espécie conhecida por ser humano, mas um autômato, um fantoche ou alguma outra categoria passível de treino e domesticação. Sem o caráter históricofilosófico dos conteúdos humanísticos no currículo, estaríamos à deriva do projeto civilizacional, rumando para a degradação e à barbárie. Claro, avaliando o que fizemos até agora, enquanto operários da cultura e do conhecimento, pois a visão de ética que pretendemos discorrer neste texto, inspirada na filosofia nietzschiana, põe em análise essa bagagem fundacional da modernidade. Por enquanto, precisamos situar nosso problema de pesquisa e a importância dos pressupostos éticos na ação pedagógica. E é nessa esteira que a ética aparece diluída nas temáticas curriculares. Quer dizer, ela não apenas existe, mas está em todos os lugares, perpassando a lógica de composição dos saberes, a base dos projetos educacionais e, por que não afirmar, a convivência entre os diversos sujeitos que interagem na jornada da formação? Nesse sentido, torna-se indissociável falarmos dessa jornada sem nos remeter aos modos de agir, à construção dos valores, deveres e normas que, naquele determinado momento, fizeram erigir um ethos para aquele tempo.

$\mathrm{E}$, ainda que pareça um padrão $\mathrm{X}$ ou $\mathrm{Y}$ de comportamento humano, não é possível apequenar o sentido desse ethos como se tivesse sido influenciado por um pensamento-único, por verdades cristalizadas e por referentes morais acerca do que seja o bem ou o mal. Simplesmente porque não existe fórmula precisa que possa dosar a formação do caráter e da virtude com o nível de autorreflexão crítica do sujeito. No entanto, a história da pedagogia ensinou que determinado ethos, influenciado por determinados princípios (morais, religiosos, políticos, culturais, econômicos), transitou (e, possivelmente, ainda transita) pela realidade das práticas curriculares. Dessa forma, tal constituição assumiu as vestes de grego, cristão, moderno, pós-moderno no decorrer da história dos povos. É como se todo o educar tivesse por finalidade a aceitação de alguma dessas tipologias, compartilhando o contexto social e cultural da vida em comunidade. Aliás, o sentido da determinação de normas, regras e valores está na abdicação da condição instintiva do ser humano, na possibilidade de direcionar a consciência à autopreservação e conservação da espécie. Entendemos que, sendo assim, há um composto de valores pré-concebidos que neutralizam o potencial criativo e dinamizador da vida (vida que quer se expressar, desenvolverse, expandir-se, afirmar-se). E, se esses valores não ampliam as condições vitais, é porque operam na direção da estagnação niilista, na desvalorização do sentido e da própria ética. Por isso, não operamos com pensamento reducionista acerca das definições tradicionais sobre tal ou qual conceito filosófico, aplicando-o numa determinada cena, a fim de explicar uma reação, um dado, um problema cuja dimensão não pode ser explicada de maneira tão precipitada. Assim é a condição de entendermos a existência de uma ética e um ethos predominante que, dado sua singularidade aparente, esconde um complexo jogo de forças. Logo tais forças são determinantes à compactação dos valores manifestos e apregoados como legítimos.

Vejamos esse esclarecimento sobre o conceito: "A ética é teoria, investigação ou explicação de um tipo de experiência humana ou forma de comportamento dos homens, o da moral, considerado, porém, na sua totalidade, diversidade e variedade" (VÁZQUEZ, 1984, p. 11). Se for 
uma teoria, ela também poderia ser ministrada como uma das disciplinas do rol curricular. No entanto, isoladamente, restrita ao conteúdo da aula, ela poderá parecer artificial, deixando de operar ações de relevância concreta. Nessa direção, temos vaga lembrança do componente curricular chamado Educação moral e cívica, determinado pelo Decreto-lei n. 869 de 12 de setembro de 1969. Nesse tempo, cantávamos diversas vezes o mesmo hino, pintávamos várias vezes a mesma bandeira (com as mesmas cores), concorríamos pelo ideal de patriota. Tudo tinha uma aura sagrada, quase dogmática. Mas a verdade é que a vida continuava cada vez mais difícil, sem perspectivas de crescimento profissional aos filhos da escola pública. Tal experiência só demonstrou a impossibilidade de cercear a ética, como uma postura moral, codificada no âmbito de uma única disciplina. Logo depois, esse decreto foi revogado pela Lei n. 8.663 de 14 de junho de 1993 e podemos pactuar com a segunda parte da afirmação feita acima: "[...]considerado, porém, na sua totalidade, diversidade e variedade". Ou seja, não existe um padrão de comportamento moral, a menos que seja imposto por alguma força de natureza conservadora, e pensá-lo dessa forma é desconhecer a matéria inacabada da espécie humana, o espaço e a liberdade para a reinvenção de si mesmo.

Essa reinvenção foi pensada pelos gregos. Com efeito, desde sua origem na Grécia antiga, tais expressões (ética, ethos) se constituem noções híbridas cuja raiz discursiva parte do próprio sentido da paideia grega. Nessa condição, observamos a seguinte passagem: "A mais alta obra de arte que o seu anelo se propôs foi a criação do Homem vivo. Os gregos viram pela primeira vez que a educação tem de ser também um processo de construção consciente" (JAEGER, 1994, p. 13). Significa a expressão de que algo deve permanecer no decorrer dos tempos, superando batalhas, epidemias, conflitos de toda a ordem. E o que permanece traz consigo a marca indelével do conhecimento, força imaterial a serviço dos alicerces da chamada civilização ocidental cristã. Trata-se da cultura como potência transformadora cuja razão encontra na vida humana o solo fértil para animar saberes os quais orientados pela ação educadora põe evidência o percurso da formação. Esse percurso não é fácil, como mostrou Platão na sua célebre Alegoria da Caverna, mas um caminho íngreme e pedregoso. Ora, por proximidade, podemos afirmar que esse caminho, quando sinalizado como "[...] um processo de construção consciente" está submetido a uma "pista de corrida" conhecida por curriculum. De maneira que: "[...] podemos dizer que no curso dessa "corrida" que é o currículo acabamos por nos tornar o que somos" (SILVA, 1999, p. 15). Verdade que essa afirmação resgata o esforço subjetivo, o retorno do eu perdido nas malhas do saber e como não há centro de convergência ao estereótipo de sujeito: cristão, branco, homem, heterossexual, o currículo também não define os traços de caráter do que possa ser concebido como bom cidadão. Esses traços são matéria da ética que estima as fermentações da cidade, da pólis, a fim de canalizar o esforço da ação política. Daí, podemos afirmar que o ethos curricular é político, mas jamais homogêneo. Ele absorve o desenvolvimento dos saberes, individualiza e estimula o cultivo de habilidades necessárias ao convívio social. No entanto é absorvido pela dinâmica cultural que lhe precede, carregando, assim, a retórica plural da composição.

Nessa composição, ele parece relativamente estável, uma vez que, no interior de uma coletividade, assimila hábitos e costumes, verdades e valores, direitos e deveres. Tal condição é demarcada pela corporeidade como artifício da mente individual. Mas essa mente, entretanto é dobrada pela atmosfera coletiva do bem-estar social. Ou seja, para além de qualquer explicação fenomenológica, importa destacar a aptidão do sujeito a repetir um padrão, seguir uma rotina, minimizar o esforço, abnegar a inteligência instintiva. Ele deve obedecer ao valor-padrão assimilado e dificilmente o questionará, seja este tributário do discurso midiático, político ou religioso. Mesmo quando incorpora as vestes de sujeito crítico, acreditando ser capaz de julgar muitos fatos, ao mesmo tempo, não passa de consumidor de ideias alheias. Desde muito cedo, ele é estimulado por 
mecanismos curriculares a criticar qualquer ocorrência apresentada, antes mesmo de compreender a obra criticada. Tal comportamento fornece a matriz ao desenvolvimento de um espírito ressentido, uma vez que parte da negação da realidade, corroendo de maneira parcial o alvo do ataque. Por isso: "Esse espírito não pode encontrar nenhum valor em sua crítica, pois desde o começo o criticado não parecia ser de muito valor e é inapto a resistir mesmo à crítica mais óbvia" (HAASE, 2011, p. 67). Essa simulação do conhecimento, ou melhor, distorção da formação cultural, é estimulada (e desenvolvida) por plataformas de mídias sociais e jornalísticas em que tudo é permitido, a filosofia é free, qualquer banalidade se transforma em notícia séria e é disseminada para o grande público, várias e várias vezes, até se tornar uma verdade incondicional. Nessa perspectiva, podemos destacar as considerações feitas pelo filósofo Nietzsche (1844-1900) na conferência "Sobre o futuro de nossos estabelecimentos de ensino" (1872). Escrito tão distante no tempo, mas tão contemporâneo nas pontuações, como, por exemplo, a influência do jornalismo como veículo de manifestação das ideias e o Estado enquanto um "mistagogo da cultura", espécie de sacerdote de rituais iniciáticos. Mas onde queremos chegar com tais apontamentos? Ora, o sujeito autônomo e livre das ideias modernas, herdeiro do Iluminismo francês, é cooptado pelo niilismo intrínseco presente na origem dessas ideias. Há uma desvalorização contínua dos saberes humanísticos em vez da edificação do cidadão portador de direitos e deveres. Parece contraditória tal afirmação, mas observe-se o tratamento dispensado aos saberes históricos filosóficos no currículo, a desvalorização do passado por um futuro incerto. Porém, mesmo incerto, ele se apresenta como promessa de salvação, coordenando a vida em coletividade pelo critério de utilidade econômica. Logo esse clima estável promovido pelo estado de direito não é isento de intenções de controle e manipulação. E se o ethos curricular é político, devemos compreender em toda a dimensão a natureza dessa ação. Ela trabalha pelo esforço radical de tornar o sujeito senhor de si mesmo, lançando a base para o desenvolvimento da vontade? Ou contribui para a desvalorização do conhecimento humano, para a vontade de negação e destruição de valores, saudáveis à vida?

\section{Ética transversal}

É nesse cenário que podemos analisar outro exemplo do currículo nacional com temática relacionada à ética. $\mathrm{Na}$ esteira do fracasso do componente Educação moral e cívica, são elaborados os chamados Parâmetros Curriculares Nacionais (PCNs, 1997, 1998). Nesse documento, a ética ressurge como tema transversal. Ou seja, compreendendo-a, dessa forma, significa o abandono do estatuto disciplinar em proveito do cruzamento temático entre as várias áreas do currículo. Não se trata da criação de algo novo, mas de pensar a complexidade conceitual quando direcionada para a formação humana. São novos tempos, depois de muitos anos de obscuridade e repressão, os PCNs surgem na esteira da constituição democrática de 1988, período em que os estados nacionais reformulam princípios em relação à vida coletiva e à preservação do meio ambiente. De certa forma, é praticado um modelo de educação direcionada para a formação cidadã que agrega noções valorativas tributárias das correntes filosóficas dos séculos XVIII e XIX (idealismo, positivismo, existencialismo, pragmatismo, fenomenologia e, sobretudo, o materialismo histórico). No entanto, é provável que a influência mais potente tenha sido a filosofia de vertente kantiana, conforme podemos observar nesta passagem: "Um homem sem dúvida pode, no que respeita à sua pessoa, e mesmo assim só por algum tempo, na parte que lhe incumbe, adiar o esclarecimento [Aufklärung]. Mas renunciar a ele, quer para si mesmo quer ainda mais para sua descendência, significa ferir $\mathrm{e}$ calcar aos pés os sagrados direitos da humanidade" (KANT, 2008, p. 69). 
Ainda que pese a tradução do termo alemão, sem correspondente exato para a língua portuguesa, a forma de compreender o "esclarecimento" é um processo de transformação pessoal (no âmbito do pensamento e das ideias), jamais uma condição imposta por alguma força externa de índole coercitiva. E, por isso, negar esse processo significa condenar as novas gerações ao retrocesso jurídico da sociedade civil organizada. Os referidos "direitos da humanidade", estampados no lema da Revolução Francesa de 1789 (liberdade, igualdade e fraternidade) são desdobrados numa série de normas políticas, administrativas, religiosas. Já sinalizamos, linhas atrás, o niilismo intrínseco das ideias modernas. Mas não havíamos discorrido quanto ao teor desse "humanismo kantiano", à importância do conhecido lema Sapere aude (ouse saber). Ora, ao invocar esse estatuto de autonomia do sujeito, Kant funda uma instância modelar de valor: a subjetividade transcendental, por meio da qual o ser humano alcança valor absoluto independentemente daquilo que um indivíduo tenha feito ou venha a fazer. Ele não está mais submetido ao jogo das forças do desenvolvimento histórico, tampouco enxerga no conhecimento a razão vital para a construção de si. De alguma forma, podemos afirmar que: "Em resumo, um sujeito humano concebido sob uma forma universal não muda nunca, encontrando por meio disso a igualdade de todos os seres humanos, quaisquer que sejam suas circunstâncias e ações" (HAASE, 2011, p. 60). Nesse sentido, tal sujeito acredita que persegue a verdadeira liberdade, mas, na verdade, aprisiona a si mesmo nas malhas do julgamento moral, pois esses valores são préconcebidos, estão prontos e definidos, basta resgatá-los como um souvenir das últimas férias de verão. E, se o sujeito já nasce pronto, como um cidadão universal, nada há mais a se fazer, nenhuma aventura mobiliza as ideias, a vida em si mesma se esvazia de sentido. Portanto o sujeito da modernidade (o último homem para Nietzsche), gerado pelo humanismo kantiano, caminha a passos largos para a doença do século, o niilismo, abdicando da efetiva ação política pela ação coordenada e representativa dos interesses de estado.

Aliás, esse é um ponto importante, porque como citado, afirmamos que o ethos curricular é político. E, conforme considerações anteriores, discutimos o projeto de educação moderna, situando-o quanto à desvalorização da cultura e do conhecimento. Importa lembrar que, na mesma conferência "Sobre o futuro de nossos estabelecimentos de ensino", Nietzsche aponta que as Universidades, os colégios e as demais instituições educacionais, considerando sua tarefa política, deveriam se situar à margem do estado, sem resquícios de influência ou qualquer forma de cooptação. Observamos que tais instituições são submetidas aos interesses econômicos e, no caso da jovem democracia brasileira, quase sempre, ao jogo de grupos políticos partidários, o que significa uma lástima para o sistema de educação nacional. Para além dessa condição, a educação moderna falha na formação dos jovens estudantes, no modo de conduzir a ação pedagógica. Nesse ponto, temos que sinalizar outra correção de sentido: o ethos curricular não é político, como tarefa acabada do agir, mas ele torna-se político enquanto potencial de formação humana. Assim, significa que a "verdadeira educação", com toda a temeridade que essa afirmação pode conter, numa perspectiva nietzschiana, caminha a fim de "tornar-se pessoa", "tornar-se humano", o que parece uma grande banalidade às tecnologias de controle de opinião que, constantemente, artificializam relações humanas, manipulam ideias, promovem a desordem e o caos. Nesse contexto, o papel da educação se restringe a insuflar o ego dos jovens profissionais, transferindo algumas habilidades para que possam se inserir no mercado de trabalho. Atrelado à economia, tal ensino artificializa a condição docente (o professor é apenas uma peça da engrenagem, sendo possível substituí-lo a qualquer momento). Existe uma iminência metafísica, na atmosfera da sala de aula, manifestando que, em algum momento, o aluno pode se tornar o professor, já que pode desejar e escolher o que deve consumir de conteúdos e o que não deve. Em consequência, há um esquecimento da tradição 
(da Paideia grega, do Bildung alemão), uma forma de desinteresse pelo valor do conhecimento e, em relação à ação política, percebemo-la esvaziada de sentido.

\section{In corpore vita}

Se essa ação não se volta à percepção de que habitamos um espaço coletivo o qual deve ser, de forma contínua melhorado, por meio da intervenção direta do indivíduo, a formação para a cidadania se reduz ao cultivo do egoísmo, ao artificialismo das relações pedagógicas. Vejamos esta passagem da filosofia antiga: "As virtudes, portanto, não são geradas em nós nem através da natureza nem contra a natureza. A natureza nos confere a capacidade de recebê-las e essa capacidade é aprimorada e amadurecida pelo hábito" (ARISTÓTELES, Ética, Liv. II, 2002, p. 65). Assim como o filósofo divide os ramos do conhecimento, em duas grandes categorias, qual sejam, as ciências teóricas (física, metafísica, psicologia, matemática...) e as ciências práticas (ética, política...), divide também as virtudes em intelectuais (prudência ou phronesis, sabedoria ou Sophia) e moral (coragem, justiça, etc.) (PAVIANI, 2013). Lembramos que, segundo Aristóteles, o homem é zoon politikon, animal político, ou seja, como espécie racional, ele nasce propenso ao exercício da práxis política direcionada para a vida na polis. Lembramos, também, que o estagirita organiza a vida humana, em três esferas: a doméstica ou do oikos, a privada (domínio da ética aplicada) e a pública (domínio da política). No entanto as duas primeiras estão submetidas à terceira, cabendo a ela determinar as regulamentações e regras de convivência. Isso porque o homem não vive só, uma vez que, de maneira isolada, não consegue atualizar sua potência vital (mesmo em Nietzsche, o solitário Zaratustra foi atrás de seus seguidores). Portanto nenhuma ação pedagógica deve visar à convergência do homem a si mesmo, submetendo-o ao risco da alienação ideológica. Ao contrário, ele encontra a si mesmo na construção da comunidade que o cerca. É livre, porque assume o gesto de liberdade, a participação ativa nas decisões da polis. Seu lugar é a ágora e não ocupar esse lugar significa estar restrito ao oikos, submeter-se e obedecer ao potestas.

Claro, essa postura também perpassa a visão que absorvemos do conhecimento humano. A Paideia grega, sobretudo de matriz platônica, ensina a conter a bagagem instintiva (por exemplo, a virtude da Aretê que, inicialmente, era uma conquista dos heróis homéricos, transforma-se em disciplina didática). E, como tal, ela pode ser ensinada e não apenas adquirida pelo direito da linhagem familiar. Todavia existem, como em todo contexto social, hábitos e atitudes provenientes da educação informal. Apenas destacamos que, por exercício da vida urbana, tais processos se formalizaram por meio da Pedagogia. Por isso, a prudência aparece como uma virtude intelectual em Aristóteles. Ela é o elo entre o saber-agir e o desenvolvimento da condição ética política do indivíduo. E ainda que esse saber-agir seja aprimorado pela experiência, ele não elimina a distância entre teoria e prática, razão e emoção, conhecimento e técnica. Ou seja, a tradição da filosofia antiga (considerando seu grande arcabouço e a diferença entre os filósofos) legou à modernidade o modelo clássico de racionalidade que afasta o corpo vivo do pensamento. Esse corpo é formado por uma memória instintiva que se tornou carne à custa do sofrimento de gerações e, por isso, sua percepção do mundo, seus sentimentos não podem ser menosprezados. Mas qual a relação dele com a ética e o currículo? Ora, esse é o corpo que será moldado pelo ethos curricular na sua derivação política. Assim sendo, ela só pode promover a vida, jamais destruí-la ou menosprezá-la, pois: "[...] vida é curso percurso transcurso" (CORAZZA, 2009, p. 41). O discurso da morte e do ódio não combina com o currículo, uma vez que o conhecimento deve estar a serviço desse corpo vivo. Então, por que não falar de amor como uma nova ética? 
...seja este, doravante, o meu amor!

No entanto, dos tipos de amor: Eros, ágape, philia, storge, e tantos outros de vários modos e sentidos, queremos afirmar que é justa toda forma de amor. No currículo, o amor é tão transversal quanto a ética, ou seja, diluído na composição de saberes, sentidos e sabores. Também na compreensão de vivências, de afetos, de solidões, de paixões, de experiências, de infindáveis leituras e preparações para a aula. Aula essa que estabelece as relações de força e potência por meio da persistência e da criação, superando a repetição da "aula-clichê" (CORAZZA, 2012, p. 25). Isso significa que há uma relação desmesurada com o instante e, por mais que a programação didática venha a determinar o controle do tempo; ainda assim, existem flashes de memória, nuance de cores, interlúdio de cenas que põe em movimento o corpo vivo de sensações. Esse corpo carregado de energia potencial quer expressar a verdade e não mais se entregar à doutrinação do sentido, ao engodo da pequena política. Ele quer a forma do agir incondicional, sem promessas de transformação por meio da realidade vindoura, apenas a afirmação deste grande amor: amor fati. E, afirmando-o dessa forma e nessa direção, estamos concebendo o indivíduo enquanto multiplicidade pulsional, sempre em combate permanente a fim de afirmar sua existência.

Por isso, ao invés de explicar determinado comportamento ético ou moral, cabe-nos o esforço da interpretação, deslocando o eixo metafísico da verdade perene para o efeito provisório da afecção. Tal procedimento também desloca o núcleo fundacional da Pedagogia e do Currículo, mormente calcados em valores judaico-cristãos, para o esforço da transvaloração dos valores. Nessa condição, o ethos não pode mais se reconhecer como uma representação do poder político, mas confere à inocência da criança o desejo da reinvenção de si mesmo. Desse modo, podemos entender que: "Vontade de potência, além-do-homem, eterno retorno e amor fati são conceitos que se interligam enquanto uma possibilidade de compreensão, isto é, uma perspectiva que conduz da interpretação dos existentes à interpretação do agir" (AZEREDO, 2003, p. 34). Essa afirmação significa a reordenação da ética moderna na direção de uma hermenêutica da vontade. Em tal condição, o motor da ação não pode ser compreendido pela intervenção de postulados morais, mas pela valoração positiva do agir, renovando vozes, sentidos e conceitos. O que significa uma forma de supressão do modo clássico de conceber o pensamento e as ideias, ou seja, essência x aparência, teoria x prática, uma vez que o mecanismo posto nessa concepção já nasce moralizado. Ao contrário, a sustentação desse agir segue a esteira da afirmação incondicional da vontade, o esforço sobre-humano em aceitar tudo o que lhe ataca, mesmo as coisas mais sórdidas e odiosas. Isso porque se abdica do raciocínio acabado como artifício da consciência e, ao mesmo tempo, das definições acerca da projeção e da finalidade da ação, o que incorre na impossibilidade de trabalhar a formação como condicionante de forças externas ao currículo. De certa forma, Nietzsche, na Genealogia da moral (1998), procura realizar uma leitura histórica filosófica de conceitos constitutivos dos valores morais (bem, mal, bom, mau...), demonstrando a fragilidade da razão na modernidade. É como se um fundo obscuro e sensível, constitutivo do ser humano, recebesse atenção e, quiçá, valor. Esse fundo (não consciente, não intencional, não temporal, não lógico) recusa uma forma de ética como fundamento, operando com perspectivas provisórias. Essas perspectivas são provisórias porque acatam a forma circunstancial de o ser humano se manifestar no mundo (se reinventando e se realocando no tempo e no espaço). Nesse sentido, concebemos uma ética do amor fati no currículo, recusando os valores estabelecidos. Sabemos, inclusive, que somente por meio do eterno retorno tal condição iria vingar. E, como temos que aceitar tudo (todo o desgosto, toda a dor, todo o sofrimento) então, mesmo os valores reativos (pertinentes ao ódio e à exploração humana) podem retornar ao currículo? Além do mais, pretendemos o além do homem como ethos criador de valores, mas, com isso, não abriremos brechas para o retorno do homem pequeno, do 
mais feio e abjeto dos homens? E como superar a estagnação niilista e o artifício da ação política no caminho da morte e da destruição? Afinal: "Entendamos bem: é o homem que se transforma, e não uma instância exterior que se substituiria bruscamente a ele" (GRANIER, 2009, p. 113).

O homem que se transforma é o além-do-homem e talvez suas lições sirvam de horizonte para as questões assinaladas. Em primeiro lugar, a lição da autossuperação é uma constante na filosofia de Nietzsche. A medida de uma ponte a outra é a capacidade de transformar tudo que é reativo em ativo, tudo o que é negativo em afirmativo (DELEUZE, 1976). Em segundo lugar, o discernimento do mundo enquanto movimento constante de destruição e criação, gerando, a cada vez, outra perspectiva sobre a vida e o conhecimento. Em terceiro lugar, o mecanismo de seleção de forças diz respeito ao acúmulo de potência, desde gerações anteriores até o instante da ação, aperfeiçoando a inteligência instintiva e seduzindo o corpo sempre a novas interpretações. Nesse sentido, o corpo significa uma unidade potencial que abdica da consciência acusatória e do dever regular da ética aplicada. Do encontro consigo (do corpo com seu artefato de sujeito), surge a percepção de que as verdades são relativas e representam metáforas da realidade. Existem outras lições sobre a transmutação do além-do-homem, mas basta afirmar que o esforço necessário para absorver, mesmo o niilismo reativo, encontra no amor fati sua mais profunda expressão. E antes que tal conceito mude de sentido (é assim na obra do filósofo), cabe uma definição: "Por amor fati, antiga expressão latina cujo sentido literal é amor ao fado (destino) ou amor à fatalidade, Nietzsche compreende o amor ao que é necessário" (RUBIRA, 2016, p. 109-110). Portanto, frente aos artifícios da moral de base gregária, o além-do-homem apresenta a postura estoica de fidelidade a si mesmo, crença no poder renovador da vida humana e na aceitação do imperativo desse amor, fatídico, porém, sumamente necessário.

No entanto é importante situá-lo na obra de Nietzsche a fim de contextualizarmos o propósito de uma ética do amor fati no currículo. Nesse sentido, é consenso entre pesquisadores que a expressão surge no período da sua filosofia madura, a saber, a partir de $1881 \mathrm{com}$ a visão do eterno retorno (MARTON, 1990). Ele aparece, assim, desde a Gaia ciência (1882), passando por Assim falava Zaratustra (1883-85) até encontrarmos referências no Caso Wagner e Ecce Homo (ambos de 1888). Excluímos, pelo critério de que não foram obras concebidas por Nietzsche em vida, os fragmentos póstumos, além de que a forma de organização e tradução desses fragmentos é motivo de controvérsias entre os estudiosos. E, tratando-se da filosofia perspectivista, é provável que, pelo momento, talvez o aforismo e o lugar, em que tal expressão aparece na obra, ela possa significar sentidos diversos, compreensões distintas. Então, vejamos na Gaia ciência, cujo significado está relacionado ao desejo de vida nova, novos projetos que se iniciam com um novo ano. A expressão aparece no início do livro IV, aforismo 276 (Para o Ano Novo): "Quero cada vez mais aprender a ver como belo aquilo que é necessário nas coisas: - assim me tornarei um daqueles que fazem belas as coisas. Amor fati [amor ao destino]: seja este, doravante, o meu amor! [...]" (NIETZSCHE, 2001, p. 187-188). Importa afirmar que o referido aforismo se encontra antes do anúncio do eterno retorno (O maior dos pesos, aforismo 341). Nesse caso, não podemos dizer que uma coisa depende da outra, mas que existe uma sintonia de eventos. Por exemplo, o ano que se acaba, o ano novo que nasce, a experiência do tempo presente que supera a melancolia em troca da promoção da inocência do espírito de maneira que podemos partilhar da seguinte afirmação: "Inocência essa proveniente da própria necessidade do agir, cuja assimilação dá-se mediante o sentimento de sua aceitação" (AZEREDO, 2003, p. 257). Entendemos que não há respaldo na organização da memória efetiva, tampouco racional, mas a emulação de forças canalizadas num único sentido (o sim dionisíaco), sendo impossível retornar ao passado ou determinar algum projeto futuro. Tratase, portanto, da aceitação do corpo todo, um estado de ânimo (êxtase pela alegria do instante), 
convergência do agir sem pressupostos de ordem moral, sem relações de causa e efeito, apenas o novo que se estabelece gerando novas perspectivas.

Outra interpretação pode ser extraída do Caso Wagner: "Minha natureza íntima me ensina que tudo necessário, visto do alto e no sentido de uma grande economia, é também vantajoso em si - deve-se não apenas suportá-lo, deve-se amá-lo... Amor fati [amor ao destino]: eis minha natureza íntima. [...]" (NIETZSCHE, 1999, p. 71). Lembramos que essa obra significa um ataque frontal a Richard Wagner (1813-1883), que, segundo Nietzsche, perverteu-se ao domínio moral do cristianismo. É como se Wagner, já no final de sua vida, tivesse se redimido da paixão dionisíaca pelo drama trágico e professado dos votos de castidade. Além do mais, sua música abdica do ideal de nobreza para partilhar valores de base gregária. Por isso, Nietzsche não se reconhece mais em Wagner. Ao venerar os instintos mais baixos, o músico abandona a perspectiva da vida ascendente (do alto) como também abdica da economia dos afetos, tanto em termos de quantidade (forças) quanto de qualidade (vontade). Nesse sentido, o próprio filósofo remete ao exemplo de superação. Com efeito, valendo-se de sua natureza doentia, ele intensifica esforços a fim de contornar a dor e o sofrimento para, assim, crescer em direção à resistência e ao acúmulo de potência.

Agora, no mesmo ano de 1888, Nietzsche apresenta o Ecce Homo, sua conhecida autobiografia filosófica. Nela também encontramos referência ao lema latino: "Minha fórmula para a grandeza no homem é amor fati: nada querer diferente, seja para trás, seja para frente, seja em toda a eternidade. Não apenas suportar o necessário, menos ainda ocultá-lo - todo idealismo é mendacidade ante o necessário — mas amá-lo...” (NIETZSCHE, 1995, p. 51). Nesse ponto ocorre proximidade com o conceito de eterno retorno, uma vez que o apelo à grandeza no homem significa a preparação do caminho para o além-do-homem. Também chamamos a atenção para essa passagem, pois a expressão amor fati não aparece como uma conquista, mas como algo que está inerente ao esforço de superação. Superação, por exemplo, do episódio da morte de deus ou, conforme a repetição cíclica dos acontecimentos, do retorno do niilismo reativo. Difícil não lembrar, inclusive, de um episódio do Zaratustra (Da visão e do enigma) quando este, após longo silêncio num barco em alto mar, começa narrar uma visão aos marinheiros: Ele tem nas costas um anão zombeteiro que carrega há algum tempo. Como um espírito da gravidade, do peso, o anão proferia uma sequência de agouros e palavras ofensivas aos ouvidos de Zaratustra. Como estavam diante de um portal, esse fala ao anão:
“Olha esse portal anão!”_Prossegui: "Ele tem duas faces. Dois caminhos aqui se juntam; ninguém ainda os percorreu até o fim.
Essa longa rua que leva para trás: dura uma eternidade. E aquela longa rua que leva para frente - é outra eternidade".
Contradizem-se, esses caminhos, dão com a cabeça um no outro; e aqui, neste portal, é onde se juntam. Mas o nome do portal está escrito no alto: "momento"1. Mas quem seguisse por um deles - e fosse sempre adiante e cada vez mais longe: pensas, anão, que esses caminhos iriam contradizer-se eternamente?
"Tudo o que é reto mente", murmurou, desdenhoso, o anão. "Toda verdade é torta, o próprio tempo é um círculo” (NIETZSCHE, 1986, p. 166).

Zaratustra detesta a resposta do anão, uma vez que ele está simplificando demais as coisas. Ora, o tempo cronológico ou o tempo cíclico são as formas conhecidas do tempo e, portanto, usuais. Em contrapartida, o tempo do eterno retorno não segue a esteira regular de compreensão do tempo. Quando Zaratustra profere "para trás" (passado) ou "para frente" (futuro), nesse

\footnotetext{
${ }^{1}$ Lembramos que, por vezes, em outras traduções da obra Assim falava Zaratustra essa expressão (o nome do portal) é traduzida por "instante".
} 
primeiro momento, é a demonstração de uma contradição, a condição de que o tempo é externo ao sujeito, por isso sua irritação com a resposta do anão. No entanto, se observarmos em seguida, nessa mesma passagem, a fala de Zaratustra: "Tudo aquilo, das coisas, que pode caminhar, não deve já, uma vez, ter percorrido esta rua? Tudo aquilo, das coisas, que pode acontecer, não deve já, uma vez, ter acontecido, passado, transcorrido?" (NIETZSCHE, 1986, p. 166). Trata-se, nesse segundo argumento, de outra relação com o portal (o momento ou instante), pois a visão de futuro e passado é absorvida no presente. Nesse presente, o tempo é plano (para trás ou para frente) e, com isso, plenamente possível de se realizar. E isso é possível porque se abdica dos valores em curso, porque o sujeito-corpo-todo está imerso nele (e nele se reconhece). Nessa direção, podemos acompanhar a seguinte colocação: "Se o tempo é um círculo, todo instante deve, necessariamente, voltar; mas se eu sou eu mesmo, o instante, para mim, é, todo instante, uma possibilidade de decidir o conteúdo desse instante que eu sou e que, em todo caso, deve forçosamente voltar" (FRANK, 2005, p. 3334). O que pode significar uma forma de superação do niilismo reativo que, mesmo retornando, pode ser convertido em ativo (em alegria). O exemplo mais próximo está na sequência dessa mesma seção, quando Zaratustra narra a visão do pastor que sofria com uma negra serpente pendendo da sua boca. Quando, ordenado por ele, esse pastor morde a cabeça da serpente e cospe fora o resto, ocorre a afirmação do instante. Ou seja, o que era sofrimento transfigurou-se em alegria, e os valores reativos (cuspidos fora) abrem espaço para novos valores, intensificados pela atividade da vontade de potência. E qual a razão de fazermos toda essa delonga acerca do conceito de amor fati pensado no currículo, utilizando passagens de Zaratustra? Ora, estamos a partir dessa passagem procurando respostas às questões sinalizadas acima: sobre o retorno do reativo e do homem pequeno, da ação política enquanto afirmação da vida, do caráter criador do ethos curricular. E, é obvio, tratando-se da filosofia de Nietzsche, de que não temos respostas, mas temos um sinal, uma ética do amor fati. Vejamos: a condição do instante (momento no portal) não pode ser metafísica, mas remete ao instante-aqui, na esfera do possível e da necessidade. Por meio dessa aceitação (podemos entender como resistência ao avanço das forças de destruição - a serpente negra que sufoca o pastor), uma fórmula se apresenta: "destruir-para-criar". Destruir os resquícios de niilismo reativo no currículo (cortar a cabeça, cuspir fora) a fim de estimular a liberdade para novas criações. De certa forma: "Abandono da má consciência. Dos dispositivos de negatividade e culpabilização. Maldito seja o pensamento depressivo" (CORAZZA, 2006, p. 65). Nesse sentido, há bons indícios de que o pensamento depressivo no currículo seja o pensamento conservador. Mesmo a nova BNCC, que, inicialmente, enseja abertura democrática na organização dos saberes, acaba restringindo conceitos, delimitando temáticas, sinalizando um modelo de ética (pressuposto como ideal para todos os cidadãos). Mas porque o pensamento conservador é tão perigoso para o currículo? Porque impede o exercício pleno da vontade de potência. O anão (o homem pequeno) é seu guia e o círculo (que roda, roda e não sai do lugar) é seu dilema. O símbolo da serpente negra (ouroboros, que devora seu próprio rabo) também é o símbolo que sufoca a voz do pastor (o discurso do ódio e da morte). Em contrapartida, intensificar esforços em direção à afirmação da vida significa expandir a alegria, o diverso, a beleza, o sonho, a magia, a boa vontade, o conhecimento, o respeito, a paz, enfim, o amor: amor fati! 


\section{CONSIDERAÇÕES FINAIS}

Ao relacionarmos ética e currículo, corremos o risco de divagar infinitamente e não chegar a lugar algum. Entretanto, os recortes efetuados e as análises desenvolvidas aqui e ali oferecem uma gama de problemas que, muito antes de tentar respondê-los, importa sua concretude no campo da educação. Foi assim que diagnosticamos o caráter reativo do ethos curricular, tributário da tradição clássica do pensamento ocidental. Ademais, também constatamos que a perspectiva do agir que anima a prática política da formação curricular desconsidera a importância do corpo vital (como núcleo imediato de realização do sujeito) na composição das matérias de ensino. O ensino da crítica pela crítica, por exemplo, como emblema da formação cidadã, contribui apenas para a formação do espírito ressentido. Assim, existe um grau de frustração, uma forma de niilismo reativo, que percorre as vivências do currículo, criando um círculo vicioso de repetição, de clichês pedagógicos que sufocam a possibilidade de explorar outras interpretações. A ética do amor fati se apresenta nessa direção, ou seja, na revitalização do agir como instante-aqui. Ela ensina a superar as forças reativas, enfrentar o discurso de ódio que assombra as escolas. Portanto, amar o destino é navegar contra a corrente do pensar educacional e, em meio a violentas tempestades, olhar o horizonte e afirmar: SIM.

\section{REFERÊNCIAS}

ARISTÓTELES. Ética a Nicômaco. Tradução Edson Bini. Bauru, São Paulo: EDIPRO, 2002.

AZEREDO, Vânia Dutra de. Nietşsche e a aurora de uma nova ética. São Paulo: Humanitas; Ijuí: Unijuí, 2008.

BRASIL. Decreto-Lei n. 869, de 12 de setembro de 1969. Diário Oficial da União. Poder Executivo, Brasília, DF, 15 setembro. 1969. Seção 1, p.7769. Disponível em https://www2.camara.leg.br/legin/fed/declei/1960-1969/decreto-lei-869-12-setembro-1969375468-publicacaooriginal-1-pe.html. Acesso em 25 jun. 2020.

BRASIL. Lei n. 8663, de 14 de junho de 1993. Diário Oficial da União. Poder Executivo, Brasília, DF, 15 junho. $1993 . \quad$ Seção $1, \quad$ p.7885. Disponível em https://www2.camara.leg.br/legin/fed/lei/1993/lei-8663-14-junho-1993-374625publicacaooriginal-1-pl.html. Acesso em 25 jun. 2020.

BRASIL. Ministério da Educação (MEC). Secretaria de Educação Fundamental (SEF). Parâmetros Curriculares Nacionais: apresentação dos temas transversais, ética. Brasília, DF: MEC/SEF, 1997b. Disponível em http://portal.mec.gov.br/seb/arquivos/pdf/livro081.pdf. Acesso em 25 jun. 2020. CORAZZA, Sandra Mara. Artistagens: filosofia da diferença e educação. Belo Horizonte: Autêntica, 2006.

CORAZZA, Sandra Mara. Currículo. In: AQUINO, Julio Groppa; CORAZZA, Sandra Mara (orgs.). Abecedário: educação da diferença. Campinas, São Paulo: Papirus, 2009, p. 40-46.

CORAZZA, Sandra Mara. Didaticário de criação: aula cheia. Porto Alegre: UFRGS, 2012. (Escrileituras cadernos de notas 3).

DELEUZE, Gilles. Nietžsche e a filosofia. Tradução Edmundo Fernandes Dias e Ruth Joffily Dias. Rio de Janeiro: Editora Rio, 1976.

FRANCK, Didier. As mortes de Deus. Tradução Alexandre Filordi de Carvalho. Cadernos Nietzssche, v. $1, \quad$ n. 19, p. 7-42, 2005. Disponível em $\underline{\text { https://gen- }}$ grupodeestudosnietzsche.net/portfolio/numero-19/. Acesso em 19 jun. 2020. 
GRANIER, Jean. Nieţssche. Tradução Denise Bottmann. Porto Alegre, Rio Grande do Sul: L\&PM, 2009.

HAASE, Ullrich. Nietşsche. Tradução Edgar da Rocha Marques. Porto Alegre: Artmed, 2011.

JAEGER, Werner. Paidéia: a formação do homem grego. Tradução Artur M. Parreira. São Paulo: Martins Fontes, 1994.

KANT, Immanuel. Textos seletos. Tradução Raimundo Vier e Floriano de Souza Fernandes. Petrópolis, Rio de Janeiro: Vozes, 2008.

MARTON, Scarlett. Nietz̧sche: das forças cósmicas aos valores humanos. São Paulo: Brasiliense, 1990.

NIETZSCHE, Friedrich. Assim falou Zaratustra. Tradução Mario da Silva. São Paulo: Círculo do Livro, 1986.

NIETZSCHE, Friedrich. Ecce homo: como alguém se torna o que é. Tradução Paulo César de Souza. São Paulo: Companhia das Letras, 1995.

NIETZSCHE, Friedrich. Genealogia da moral: uma polêmica. Tradução Paulo César de Souza. São Paulo: Companhia das Letras, 1998.

NIETZSCHE, Friedrich. O caso Wagner: um problema para músicos/ Nietzsche contra Wagner: dossiê de um psicólogo. Tradução Paulo César de Souza. São Paulo: Companhia das Letras, 1999.

NIETZSCHE, Friedrich. A gaia ciência. Tradução Paulo César de Souza. São Paulo: Companhia das Letras, 2001.

NIETZSCHE, Friedrich. Escritos sobre educação. Tradução Noéli Correia de Melo Sobrinho. Rio de Janeiro: Ed. PUC-Rio; São Paulo: Loyola, 2003.

PAVIANI, Jayme. As origens da ética em Platão. Petrópolis, Rio de Janeiro: Vozes, 2013.

RUBIRA, Luís. Amor fati. In: MARTON, Scarlett [editora responsável]. Dicionário Nietæ̧sche. São Paulo: Edições Loyola, 2016, p. 109-111.

SILVA, Tomaz Tadeu da. Documentos de identidade: uma introdução às teorias do currículo. Belo Horizonte: Autêntica, 1999.

VÁZQUEZ, Adolfo Sanches. Ética. Tradução João Dell'Anna. Rio de Janeiro: Civilização Brasileira, 1984.

\section{Informações do autor}

Deniz Alcione Nicolay

Programa de Pós-Graduação em Ensino de Ciências/Universidade Federal da Fronteira Sul/Grupo de pesquisa em filosofia, literatura e artes na educação (Gphília).

E-mail: deniznicolav@uffs.edu.br

ORCID: https://orcid.org/0000-0003-4218-3573

Link Lattes: http://lattes.cnpq.br/3584853627711259 